\title{
Increased fracture risk in patients with type 2 diabetes mellitus: An overview of the underlying mechanisms and the usefulness of imaging modalities and fracture risk assessment tools
}

Citation for published version (APA):

de Waard, E. A. C., van Geel, T. A. C. M., Savelberg, H. H. C. M., Koster, A., Geusens, P. P. M. M., \& van den Bergh, J. P. W. (2014). Increased fracture risk in patients with type 2 diabetes mellitus: An overview of the underlying mechanisms and the usefulness of imaging modalities and fracture risk assessment tools. Maturitas, 79(3), 265-274. https://doi.org/10.1016/j.maturitas.2014.08.003

Document status and date:

Published: 01/01/2014

DOI:

10.1016/j.maturitas.2014.08.003

Document Version:

Publisher's PDF, also known as Version of record

Document license:

Taverne

Please check the document version of this publication:

- A submitted manuscript is the version of the article upon submission and before peer-review. There can be important differences between the submitted version and the official published version of record. People interested in the research are advised to contact the author for the final version of the publication, or visit the DOI to the publisher's website.

- The final author version and the galley proof are versions of the publication after peer review.

- The final published version features the final layout of the paper including the volume, issue and page numbers.

Link to publication

\footnotetext{
General rights rights.

- You may freely distribute the URL identifying the publication in the public portal. please follow below link for the End User Agreement:

www.umlib.nl/taverne-license

Take down policy

If you believe that this document breaches copyright please contact us at:

repository@maastrichtuniversity.nl

providing details and we will investigate your claim.
}

Copyright and moral rights for the publications made accessible in the public portal are retained by the authors and/or other copyright owners and it is a condition of accessing publications that users recognise and abide by the legal requirements associated with these

- Users may download and print one copy of any publication from the public portal for the purpose of private study or research.

- You may not further distribute the material or use it for any profit-making activity or commercial gain

If the publication is distributed under the terms of Article 25fa of the Dutch Copyright Act, indicated by the "Taverne" license above,

Download date: 26 Apr. 2023 
Review

\title{
Increased fracture risk in patients with type 2 diabetes mellitus: An overview of the underlying mechanisms and the usefulness of imaging modalities and fracture risk assessment tools
}

\author{
Ellis A.C. de Waard ${ }^{\mathrm{a}, *}$, Tineke A.C.M. van Geel ${ }^{\mathrm{b}}$, Hans H.C.M. Savelberg ${ }^{\mathrm{c}}$, \\ Annemarie Koster ${ }^{\mathrm{d}}$, Piet P.M.M. Geusens ${ }^{\mathrm{e}, \mathrm{f}}$, Joop P.W. van den Bergh ${ }^{\mathrm{a}, \mathrm{f}, \mathrm{g}}$ \\ a Maastricht University Medical Centre/NUTRIM, Department of Internal Medicine, Subdivision of Rheumatology, P.0. Box 5800, 6202 AZ Maastricht, The \\ Netherlands \\ ${ }^{\mathrm{b}}$ Maastricht University/CAPHRI and NUTRIM, Department of Family Medicine, P.O. Box 616, 6200MD Maastricht, The Netherlands \\ ${ }^{\mathrm{c}}$ Maastricht University Medical Centre/NUTRIM, Department of Human Movement Science, P.O. Box 5800, 6202 AZ Maastricht, The Netherlands \\ ${ }^{\mathrm{d}}$ Maastricht University/CAPHRI, Department of Social Medicine, School for Public Health and Primary Care, P.0. Box 5800, 6202 AZ Maastricht, The \\ Netherlands \\ e Maastricht University Medical Centre/CAPHRI, Department of Internal Medicine, Subdivision of Rheumatology, P.O. Box 5800, 6202 AZ Maastricht, The \\ Netherlands \\ ${ }^{\mathrm{f}}$ University of Hasselt, Biomedical Research Institute, P.O. Box 6, 3590 Diepenbeek, Belgium \\ ${ }^{g}$ VieCuri Medical Centre, Department of Internal Medicine, Subdivision of Endocrinology, P.O. Box 1926, 5900 BX Venlo, The Netherlands
}

\section{A R T I C L E I N F O}

\section{Article history:}

Received 1 August 2014

Accepted 6 August 2014

Keywords:

Type 2 diabetes mellitus

Fractures

Bone quality

Fall risk

Bone mass

\begin{abstract}
A B S T R A C T
Type 2 diabetes mellitus has recently been linked to an increased fracture risk. Since bone mass seems to be normal to elevated in patient with type 2 diabetes, the increased fracture risk is thought to be due to both an increased falling frequency and decreased bone quality. The increased falling frequency is mainly a result of complications of the disease such as a retinopathy and polyneuropathy. Bone quality is affected through changes in bone shape, bone micro-architecture, and in material properties such as bone mineralization and the quality of collagen. Commonly used methods for predicting fracture risk such as dual energy X-ray absorptiometry and fracture risk assessment tools are helpful in patients with type 2 diabetes mellitus, but underestimate the absolute fracture risk for a given score. New imaging modalities such as high resolution peripheral quantitative computed tomography are promising for giving insight in the complex etiology underlying the fragility of the diabetic bone, as they can give more insight into the microarchitecture and geometry of the bone. We present an overview of the contributing mechanisms to the increased fracture risk and the usefulness of imaging modalities and risk assessment tools in predicting fracture risk in patients with type 2 diabetes.
\end{abstract}

(C) 2014 Elsevier Ireland Ltd. All rights reserved.

\section{Contents}

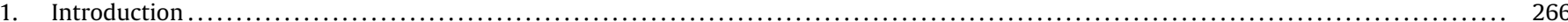

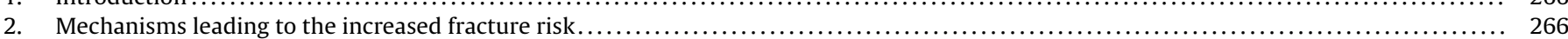

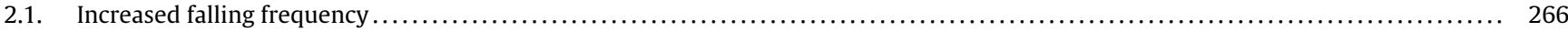

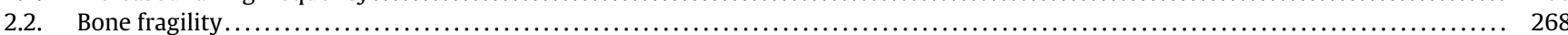

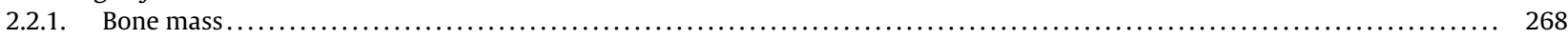

\footnotetext{
Abbreviations: AGE, advanced glycation end product; aBMD, areal bone mineral density; BMD, bone mineral density; BMI, body mass index; DPP-4, dipeptidyl peptidase4; DXA, dual-energy X-ray absorptiometry; eBMD, estimated bone mineral density; GLP-1, glucagon-like peptide 1; HbA1c, glycated hemoglobin; PPAR- $\gamma$, peroxisome proliferator-activated receptor-gamma; PTH, parathyroid hormone; SGLT2, sodium-glucose transport protein 2; T2DM, type 2 diabetes mellitus; TZD, thiazolidinedione; vBMD, volumetric bone mineral density; WHO, World Health Organization.

* Corresponding author. Tel.: +31 644523706 .

E-mail address: e.dewaard@maastrichtuniversity.nl (E.A.C. de Waard).
} 


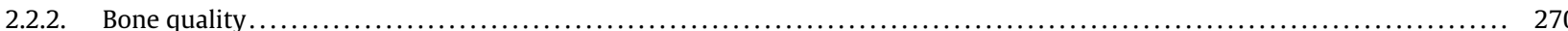

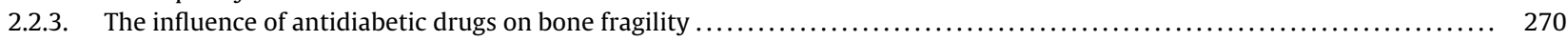

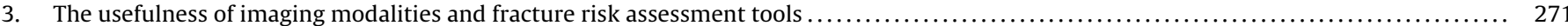

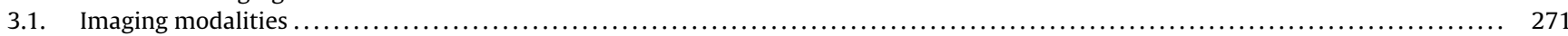

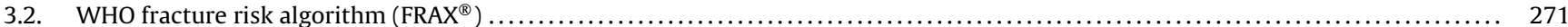

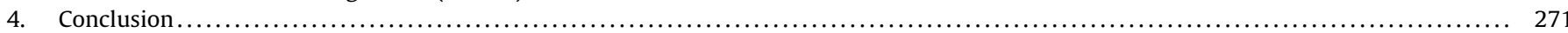

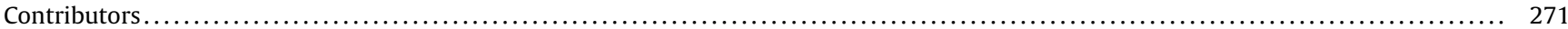

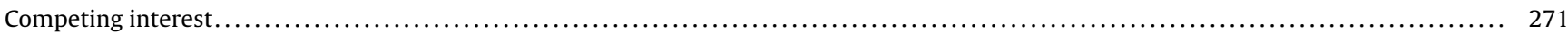

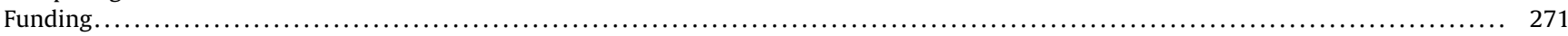

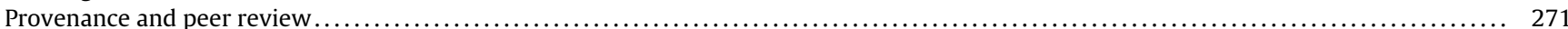

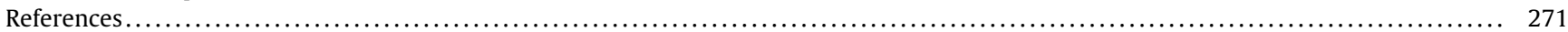

\section{Introduction}

Type 2 diabetes mellitus (T2DM) is a highly prevalent disease, especially in elderly and obese patients. Since the world population is aging and worldwide obesity has nearly doubled since $1990[1,2]$, the number of T2DM patients is expected to increase continuously. In 2011 it was estimated that 347 million adults worldwide suffer from diabetes [3]. Ninety percent of all diabetic patients can be classified as type 2 diabetics [4]. T2DM is characterized by insulin resistance and a relative deficiency of insulin, leading to a hyperglycemic state. Long term hyperglycemia results in end organ dysfunction such as neuropathy, retinopathy, cardiovascular disease and nephropathy, making diabetes one of the most important causes of morbidity and mortality in the western world.

More recently, an increased fracture risk has been suggested as another complication of T2DM [5]. Over the past ten years, the relationship between T2DM and overall, hip, vertebral and wrist fracture risk has been studied extensively [5-23]. For vertebral and wrist fractures it is not clear yet whether fracture risk is higher than or comparable to fracture risk in nondiabetic subjects, but hip and overall fracture risk seem to be evidently increased in T2DM patients (an overview of the literature published in the past ten years is presented in Tables 1-4). Fracture risk seems only to be increased in patients with already established T2DM, while patients with newly diagnosed T2DM or with an impaired glucose tolerance or impaired fasting glucose have a fracture risk lower than or comparable to nondiabetic subjects $[9,13,16]$.

In the general population, dual energy X-ray absorptiometry (DXA) is the most commonly used imaging modality to diagnose subjects with osteopenia and osteoporosis and therefore to identify subjects with an increased fracture risk. In T2DM patients, bone mineral density (BMD), as measured with DXA, seems to be normal to elevated [17]. As fracture risk in these patients is higher than would be expected based on their BMD score, other skeletal and extra-skeletal factors should play a role in the increased fracture risk in T2DM.

In this overview we discuss the possible mechanisms leading to the increased fracture risk and the usefulness of current and new imaging modalities and risk assessment strategies in T2DM patients.

\section{Mechanisms leading to the increased fracture risk}

In general, the mechanisms leading to fractures can be categorized in four groups: 1 . An increased falling frequency; 2 . Bone fragility; 3 . A combination of both an increased falling frequency and bone fragility; and 4 . Neither an increased falling frequency nor fragile bones. In T2DM patients, the increased fracture risk partly remains after adjusting for their increased falling frequency, thereby indicating that the increased fracture risk in T2DM patients is probably due to a combination of both an increased falling frequency and bone fragility (Tables 1-4). Below we will discuss some of the mechanisms that lead to an increased falling frequency and factors that cause bone fragility in T2DM patients (see Fig. 1).

\subsection{Increased falling frequency}

The prevalence of fall incidents is increased in older T2DM patients compared to older adults without diabetes [7,24], whereby T2DM females report more falling incidents than their male counterparts [25]. An increased falling frequency can be observed in both home dwelling T2DM subjects and T2DM subjects living in nursing homes [26]. Younger T2DM patients have a fall frequency comparable to healthy subjects, but because of a worse performance in a timed up and go test (a functional mobility test) when compared to nondiabetic subjects, there fall risk seems to be increased [27]. T2DM patients who have reported a fall in the previous year, are also more likely to have had a prior fracture [28].

Diabetic neuropathy, visual impairment due to diabetic retinopathy, vestibular dysfunction, cognitive impairment and muscle weakness of the lower limbs are common complications of diabetes mellitus, especially in case of longstanding and/or poorly regulated T2DM. All of these complications are associated with an increased risk of falling [24,28-33].

Neuropathy leads to sensory, motor and autonomic dysfunction and hence to neuropathic pain, balance problems, orthostatic hypotension and great variability in step length and step velocity [29,31,34-36], which are all factors associated with falling. Because of neuromuscular impairment, T2DM patients are predisposed to severe falls and to falls to the side, which are both risk factors for hip fractures $[37,38]$. Cognitive impairment is associated with a decline in walking speed and in gait abnormalities as well [24,39], and could therefore increase the risk of falls in T2DM patients.

Orthostatic hypotension and orthostatic complaints are more common T2DM patients when compared to subjects without diabetes [36,40]. No association between an increased risk of falls and orthostatic hypotension in T2DM patients is found, but the presence of orthostatic complaints is associated with an increased risk of falls, even in patients without established orthostatic hypotension [36]. A strong relationship between orthostatic complaints and initial hypotension (within $15 \mathrm{~s}$ after standing up) has been described [41], indicating that the association between orthostatic complaints and falls is probably due to early orthostatic hypotension.

The number of prescribed medications was also reported to be related to fall risk $[24,31,42]$. The use of four or more prescribed medications was associated with an increased fall risk [42]. As T2DM patients take nine medications on average (seven without their antidiabetic drugs) compared to an average of four prescriptions in nondiabetic subjects [24], polypharmacy could be another contributing factor to the increased fall risk in T2DM patients. 
Table 1

Hip fracture risk in diabetic patients compared to healthy subjects.

\begin{tabular}{|c|c|c|c|c|c|c|c|}
\hline Reference & $\begin{array}{l}\text { Study } \\
\text { design }\end{array}$ & Sex & N T2DM & N IGT & N NDM & $\begin{array}{l}\text { Results T2DM vs NDM } \\
(95 \% \mathrm{CI})\end{array}$ & $\begin{array}{l}\text { Results RR IGT } \\
\text { vs NDM (95\% } \\
\text { CI) }\end{array}$ \\
\hline $\begin{array}{l}\text { de Liefde et al. } \\
\text { (2004) [9] }\end{array}$ & Cohort & Both & $\begin{array}{l}778 \text { ( } 424 \text { newly } \\
\text { diagnosed, } 354 \\
\text { treated) }\end{array}$ & 1543 & 4320 & $\begin{array}{l}\text { Adjusted HR } \mathrm{HR}^{\mathrm{d}} \text { newly } \\
\text { diagnosed: } 0.86 \\
(0.45-1.64) \\
\text { Adjusted HR treated: } \\
1.64(0.89-3.02)\end{array}$ & $\begin{array}{l}\text { Adjusted HR: } \\
1.08 \\
(0.74-1.57)\end{array}$ \\
\hline $\begin{array}{l}\text { Ahmed et al. (2005) } \\
\text { [13] }\end{array}$ & Cohort & Both & $373\left(175 \sigma^{7}, 198\right.$ o $)$ & - & $\begin{array}{l}26,704(12,639 \\
\left.\sigma^{2}, 14,065 \text { + }\right)\end{array}$ & $\begin{array}{l}\text { Adjusted RR }{ }^{\mathrm{a}} \sigma^{7}: 1.63 \\
(0.59-4.5) \\
\text { Adjusted RR } \text { }: 1.9 \\
(1.04-3.49)\end{array}$ & - \\
\hline $\begin{array}{l}\text { Gerdhem et al. } \\
\text { (2005) [15] }\end{array}$ & Cohort & q & 74 & - & 1058 & RR 0.54 (0.20-1.49) & - \\
\hline $\begin{array}{l}\text { Bonds et al. (2006) } \\
\text { [8] }\end{array}$ & Cohort & q & 5285 & - & 88,120 & $\begin{array}{l}\text { Adjusted RR }{ }^{\mathrm{b}}: 1.46 \\
(1.17-1.83)\end{array}$ & - \\
\hline $\begin{array}{l}\text { Dobnig et al. (2006) } \\
\text { [22] }\end{array}$ & Cohort & q & 583 & - & 1081 & $\begin{array}{l}\text { Adjusted HR } \mathrm{HR}^{\mathrm{c}} 1.46 \\
(1.25-1.81)\end{array}$ & - \\
\hline $\begin{array}{l}\text { Janghorbani et al. } \\
\text { (2006) [16] }\end{array}$ & Cohort & q & 8348 & - & 101,343 & $\begin{array}{l}\text { Adjusted } \mathrm{RR}^{\mathrm{f}} 2.2 \\
(1.8-2.7)\end{array}$ & - \\
\hline $\begin{array}{l}\text { Leslie et al. (2007) } \\
\quad \text { [17] }\end{array}$ & Cohort & Both & $\begin{array}{l}82,094 \text { ( } 42,874 \\
\text { newly diagnosed, } \\
16,081 \text { short } \\
\text { duration, } 23,139 \\
\text { long duration) }\end{array}$ & - & 236,682 & $\begin{array}{l}\text { RR newly diagnosed: } \\
0.83 \text { (0.75-0.92) } \\
\text { RR short term: } 1.13 \\
(1.00-1.28) \\
\text { RR long term: } 1.40 \\
(1.28-1.53)\end{array}$ & - \\
\hline $\begin{array}{l}\text { Chen et al. (2008) } \\
\text { [14] }\end{array}$ & Cohort & Both & 484,787 & - & 485,034 & $\begin{array}{l}\sigma^{7}: 1.28(1.21-1.34) \\
\text { ㅇ: } 1.72(1.66-1.78)\end{array}$ & - \\
\hline $\begin{array}{l}\text { Hothersall et al. } \\
\text { (2014) [23] }\end{array}$ & Cohort & Both & 180,841 & - & 3.66 million & $\begin{array}{l}\text { Adjusted }^{\mathrm{e}} \text { IRR } \sigma^{7}: 0.97 \\
(0.92-1.02) \\
\text { Adjusted IRR } 0: 1.05 \\
(1.01-1.10)\end{array}$ & \\
\hline $\begin{array}{l}\text { Lipscombe et al. } \\
\text { (2007) [18] }\end{array}$ & Cohort & Both & $\begin{array}{l}197,412(100,322 \\
\left.\sigma^{7}, 97,090 \text { o }\right)\end{array}$ & - & $\begin{array}{l}401,400 \\
\left(202,875 \sigma^{7},\right. \\
198,525 \text { ㅇ })\end{array}$ & $\begin{array}{l}\sigma^{7}: 1.18(1.12-1.24) \\
\text { o: } 1.11(1.08-1.115)\end{array}$ & - \\
\hline $\begin{array}{l}\text { Melton et al. (2008) } \\
\text { [7] }\end{array}$ & Cohort & Both & 1964 & - & - & $\begin{array}{l}\text { SIR overall: } 1.1 \\
(0.9-1.4) \\
\text { SIR long term: } 1.5 \\
(1.1-1.9)\end{array}$ & - \\
\hline $\begin{array}{l}\text { Vestergaard et al. } \\
\text { (2005) [5] }\end{array}$ & Case-control & Both & 9598 & - & 484,657 & $\begin{array}{l}\text { Adjusted OR }{ }^{g} 1.38 \\
(1.18-1.60)\end{array}$ & - \\
\hline $\begin{array}{l}\text { Vestergaard et al. } \\
\text { (2007) [12] }\end{array}$ & $\begin{array}{l}\text { Meta- } \\
\text { analysis }\end{array}$ & Both & - & - & - & RR 1.38 (1.25-1.53) & - \\
\hline
\end{tabular}

a Adjusted for age, BMI, smoking, mean blood pressure, HDL and triglycerides.

b Adjusted for ethnicity, weight, height, time-dependent history of falls, previous fracture, history of osteoporosis, trouble seeing at baseline, alcohol or tobacco use, calcium and vitamin D intake, exercise, bisphosphonate, estrogen, steroid, insulin, selective estrogen receptor modulator or thyroid hormone use.

c Adjusted for age, weight and calcaneal bone mass.

d Adjusted for age, gender, BMI, smoking, serum creatinine, visual acuity, falling frequency and lower limb disability.

e Adjusted for age, calendar year and Scottish Index of Multiple Deprivation.

${ }^{\mathrm{f}}$ Adjusted for age, BMI, physical activity, menopausal status, estrogen use, smoking, daily intake of calcium, vitamin D and protein

g Adjusted for use of antidiabetic drugs, prior fracture, corticosteroid use, use of anti-epileptic drugs, use of diuretics, use of anxiolytics and sedatives, use of neuroleptics,

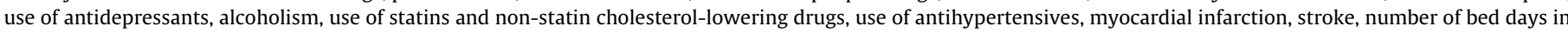
1999, number of contacts to GP or specialists in 1999, working or not, income, living with another person vs living alone.

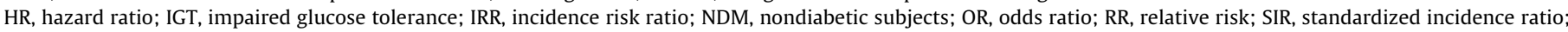
T2DM, Type 2 diabetes mellitus.

Table 2

Vertebral fracture risk in diabetic patients compared to healthy subjects.

\begin{tabular}{|c|c|c|c|c|c|}
\hline Reference & Study design & Sex & N T2DM & N NDM & Result T2DM vs NDM (95\% CI) \\
\hline Gerdhem et al. (2005) [15] & Cohort & q & 74 & 1058 & RR $0.52(0.19-1.42)$ \\
\hline Bonds et al. (2006) [8] & Cohort & o & 5285 & 88,120 & Adjusted $\mathrm{RR}^{\mathrm{a}}: 1.27(1.00-1.61)$ \\
\hline Melton et al. (2008) [7] & Cohort & Both & 1964 & - & $\operatorname{SIR} 2.8(2.4-3.2)$ \\
\hline Yamatoto et al. (2009) [20] & Cohort & Both & $298\left(161 \sigma^{\pi}, 137\right.$ 우 $)$ & $754\left(132 \sigma^{7}, 622\right.$ o $)$ & OR ơ : 4.73 (2.19-10.20), OR o : 1.86 (1.11-3.12) \\
\hline Chung et al. (2013) [21] & Cross-sectional & 우 & 2239 & - & OR: 1.03 per 1 year (1.02-1.04), Adjusted $R^{\mathrm{b}}: 2.5$ \\
\hline Vestergaard et al. (2005) [5] & Case-control & Both & 9598 & 484,657 & Adjusted $\mathrm{OR}^{\mathrm{c}}: 1.34(0.97-1.86)$ \\
\hline Vestergaard et al. (2007) [12] & Meta-analysis & Both & 10,720 & 494,516 & RR: $0.93(0.63-1.37)$ \\
\hline
\end{tabular}

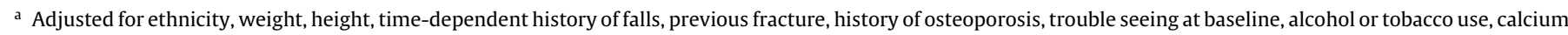
and vitamin D intake, exercise, bisphosphonate, estrogen, steroid, insulin, selective estrogen receptor modulator or thyroid hormone use.

b Adjusted for age, BMD.

c Adjusted for use of antidiabetic drugs, prior fracture, corticosteroid use, use of anti-epileptic drugs, use of diuretics, use of anxiolytics and sedatives, use of neuroleptics,

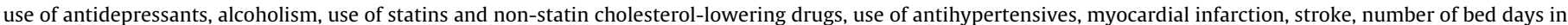
1999, number of contacts to GP or specialists in 1999, working or not, income, living with another person vs living alone.

NDM, nondiabetic subjects; OR, odds ratio; RR, relative risk; SIR, standardized incidence ratio; T2DM, Type 2 diabetes mellitus. 
Table 3

Wrist fracture risk in diabetic patients compared to healthy subjects.

\begin{tabular}{|c|c|c|c|c|c|c|c|}
\hline Reference & Study design & Sex & N T2DM & N IGT & N NDM & $\begin{array}{l}\text { Results T2DM vs NDM } \\
(95 \% \mathrm{CI})\end{array}$ & $\begin{array}{l}\text { Results RR IGT } \\
\text { vs NDM (95\% } \\
\text { CI) }\end{array}$ \\
\hline $\begin{array}{l}\text { de Liefde et al. } \\
\text { (2004) [9] }\end{array}$ & Cohort & Both & $\begin{array}{l}778 \text { ( } 424 \text { newly } \\
\text { diagnosed, } 354 \\
\text { treated) }\end{array}$ & 1543 & 4320 & $\begin{array}{l}\text { Adjusted HR } \mathrm{HR}^{\mathrm{a}} \text { newly } \\
\text { diagnosed: } 0.73 \\
(0.29-1.01) \\
\text { Adjusted HR treated: } \\
2.04 \\
(1.08-3.85)\end{array}$ & $\begin{array}{l}\text { Adjusted HR: } \\
0.58 \\
(0.37-0.91)\end{array}$ \\
\hline $\begin{array}{l}\text { Gerdhem et al. } \\
\text { (2005) [15] }\end{array}$ & Cohort & q & 74 & - & 1058 & RR: $0.62(0.33-1.16)$ & - \\
\hline $\begin{array}{l}\text { Bonds et al. (2006) } \\
\text { [8] }\end{array}$ & Cohort & q & 5285 & - & 88,120 & $\begin{array}{l}\text { Adjusted RR }{ }^{\mathrm{b}}: 1.02 \\
(0.85-1.22)\end{array}$ & - \\
\hline $\begin{array}{l}\text { Melton et al. (2008) } \\
\text { [7] }\end{array}$ & Cohort & Both & 1964 & - & - & SIR: $1.2(0.9-1.5)$ & - \\
\hline $\begin{array}{l}\text { Vestergaard et al. } \\
\text { (2005) [5] }\end{array}$ & Case-control & Both & 9598 & - & 484,657 & $\begin{array}{l}\text { Adjusted } \mathrm{OR}^{\mathrm{c}}: 1.21 \\
(1.01-1.45)\end{array}$ & - \\
\hline $\begin{array}{l}\text { Vestergaard et al. } \\
\text { (2007) [12] }\end{array}$ & Meta-analysis & Both & 10,720 & - & 494,516 & RR $1.19(1.01-1.41)$ & - \\
\hline
\end{tabular}

a Adjusted for ethnicity, weight, height, time-dependent history of falls, previous fracture, history of osteoporosis, trouble seeing at baseline, alcohol or tobacco use, calcium and vitamin D intake, exercise, bisphosphonate, estrogen, steroid, insulin, selective estrogen receptor modulator or thyroid hormone use.

b Adjusted for age, gender, BMI, smoking, serum creatinine, visual acuity, falling frequency and lower limb disability.

c Adjusted for use of antidiabetic drugs, prior fracture, corticosteroid use, use of anti-epileptic drugs, use of diuretics, use of anxiolytics and sedatives, use of neuroleptics,

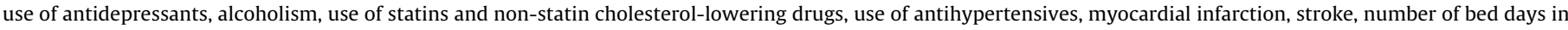
1999 , number of contacts to GP or specialists in 1999, working or not, income, living with another person vs living alone.

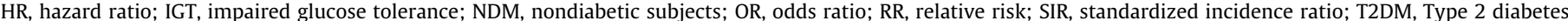
mellitus.

\subsection{Bone fragility}

Bone strength is a result of many factors, including bone mass (bone quantity) and bone quality [43]. A decrease in bone mass, a diminished bone quality and/or changes in bone geometry can therefore result in bone fragility.

\subsubsection{Bone mass}

There is extensive literature available about areal bone mineral density (aBMD) measurements using DXA in T2DM patients. Two recent meta-analyses as well as two recent systematic reviews concluded that BMD in T2DM patients seems to be normal to elevated when compared to nondiabetic subjects, even after adjustment for body mass index (BMI) [17,44-46].

With quantitative ultrasound, the estimated bone mineral density (eBMD) can be calculated. eBMD is derived from the stiffness index, which in turn is derived from both the speed of sound and the broadband ultrasound attenuation [47]. Using quantitative ultrasound, an increase in eBMD was observed in T2DM patients compared to nondiabetic subjects [28].

High resolution peripheral quantitative computed tomography (HR-pQCT) is a new non-invasive three-dimensional imaging modality. It has the ability to measure volumetric bone mineral density (vBMD), which is, in comparison to aBMD, a more accurate presentation of bone mineralization [48]. vBMD of the trabecular bone of both the radius and tibia is significantly higher in T2DM patients when compared to nondiabetic subjects [49,50], which is in agreement with the increased values of aBMD and eBMD.

Little is known about longitudinal changes in BMD in T2DM patients. Some studies showed an increased bone loss at the hip in type 2 diabetic women despite an elevated baseline BMD $[12,51,52]$, but no difference in bone loss rates could be found in

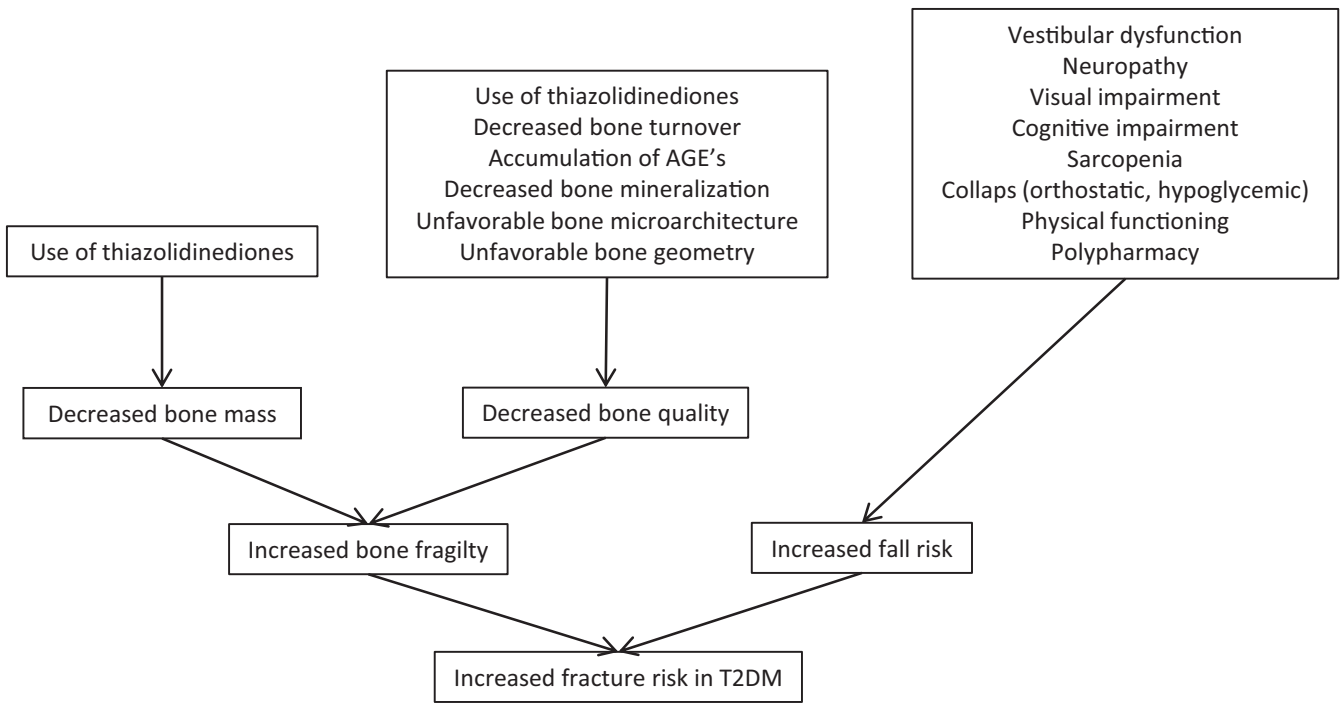

Fig. 1. Underlying mechanisms of the increased fracture risk in T2DM patients. AGE's; advanced glycated end products. 
Table 4

Overall fracture risk in diabetic patients compared to healthy subjects.

\begin{tabular}{|c|c|c|c|c|c|c|c|c|c|}
\hline Reference & Study design & Sex & N T2DM & N IFG & N IGT & N NDM & Results T2DM vs NDM ( $95 \% \mathrm{CI}$ ) & $\begin{array}{l}\text { Results RR IFG } \\
\text { vs NDM (95\% } \\
\text { CI) }\end{array}$ & $\begin{array}{l}\text { Results RR IGT } \\
\text { vs NDM (95\% } \\
\text { CI) }\end{array}$ \\
\hline de Liefde et al. (2004) [9] & Cohort & Both & $\begin{array}{l}778 \text { (424 newly } \\
\text { diagnosed, } 354 \\
\text { treated) }\end{array}$ & - & 1543 & 4320 & $\begin{array}{l}\text { Adjusted } \mathrm{HR}^{\mathrm{c}} \text { newly } \\
\text { diagnosed: } 0.82(0.56-1.18) \\
\text { Adjusted HR treated: } 1.68 \\
(1.20-2.36)\end{array}$ & - & $\begin{array}{l}\text { Adjusted HR: } \\
0.83 \\
(0.67-1.02)\end{array}$ \\
\hline Ahmed et al. (2005) [13] & Cohort & Both & $373\left(1750^{7}, 198\right.$ ○) & - & - & $\begin{array}{l}26,704(12,639 \\
\left.0^{7}, 14,065 \text { o }\right)\end{array}$ & $\begin{array}{l}\text { Adjusted } \mathrm{RR}^{\mathrm{a}} \mathrm{O}^{\top}: 1.21 \\
(0.6-2.47) \\
\text { Adjusted RR } \odot: 1.08 \\
(0.7-1.67)\end{array}$ & - & - \\
\hline Gerdhem et al. (2005) [15] & Cohort & q & 74 & - & - & 1058 & RR: $0.83(0.52-1.33)$ & - & - \\
\hline Strotmeyer et al. (2005) [6] & Cohort & Both & 566 & 177 & - & 2236 & Adjusted RR $: 1.71(1.11-2.61)$ & $\begin{array}{l}\text { Adjusted RR: } \\
1.42 \\
(0.72-2.83)\end{array}$ & - \\
\hline Bonds et al. (2006) [8] & Cohort & ㅇ & 5285 & - & - & 88,120 & Adjusted RR ${ }^{b}: 1.20(1.11-1.30)$ & - & - \\
\hline Leslie et al. (2007) [17] & Cohort & Both & $\begin{array}{l}82,094 \text { ( } 42,874 \\
\text { newly diagnosed, } \\
16,081 \text { short } \\
\text { duration, } 23,139 \\
\text { long duration) }\end{array}$ & - & - & 236,682 & $\begin{array}{l}\text { RR newly diagnosed: } 0.91 \\
(0.86-0.95) \\
\text { RR short term: } 1.00(0.93-1.07) \\
\text { RR long term: } 1.15(1.09-1.22)\end{array}$ & - & - \\
\hline Melton et al. (2008) [7] & Cohort & Both & 1964 & - & - & - & SIR $1.3(1.2-1.4)$ & - & - \\
\hline Khalil et al., 2011 [10] & Cohort & q & 117 & - & - & 2054 & Adjusted RR ${ }^{\mathrm{d}}: 1.81(1.05-3.12)$ & - & - \\
\hline Vestergaard et al., 2005 [5] & Case-control & Both & 9598 & - & - & 484,657 & Adjusted $\mathrm{OR}^{\mathrm{f}}: 1.19(1.11-1.27)$ & - & - \\
\hline $\begin{array}{l}\text { Vestergaard et al., } 2007 \\
\text { [12] }\end{array}$ & Meta-analysis & Both & 10,720 & - & - & 494,516 & RR: $0.96(0.57-1.61)$ & - & - \\
\hline
\end{tabular}

a Adjusted for age, BMI, smoking, mean blood pressure, HDL and triglycerides.

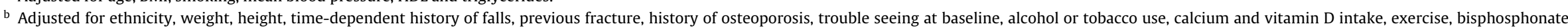
estrogen, steroid, insulin, selective estrogen receptor modulator or thyroid hormone use.

c Adjusted for age, gender, BMI, smoking, serum creatinine, visual acuity, falling frequency and lower limb disability.

${ }^{d}$ Adjusted for past history of fractures, age, weight, smoking, lifestyle (alcohol drinks/day, physical activity, clinic, health and economic status), vitamin D, calcium use, baseline hip BMD, ethnicity.

e Adjusted for sex, race, age, site, BMD.

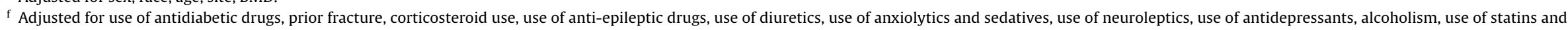

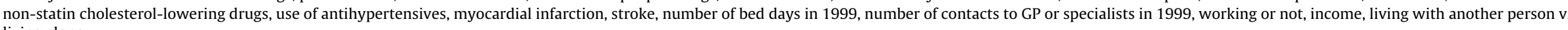
living alone.

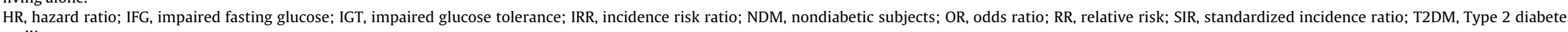
mellitus. 
T2DM men or black women [12,52]. This suggests that there might be racial or gender differences in bone metabolism, which could be due to differences in body composition and differences in sex hormones (e.g. postmenopausal status in most studied women).

It is not completely clear whether duration of T2DM is associated with BMD. Some studies did not found an association between BMD and duration of the disease [53-55], but others did show a negative association [56-59]. As the studies that were not able to find an association between BMD and duration of the disease did not include any patients with a very long duration ( $>20$ years) of the disease, the lack between an association between BMD and duration of the disease in this studies could be due to population bias.

The influence of glucose control (defined as mean glycated hemoglobin (HbA1c)) on BMD is also not completely understood, as the results from the performed studies vary from a positive $[22,44]$ to a negative $[60,61]$ correlation. Most studies however did not find a correlation at all between HbA1c and BMD [53-55,58,59].

\subsubsection{Bone quality}

Bone quality is defined as the totality of features and characteristics that influence a bone's ability to resist fracture [62] and is determined by bone (micro)architecture and by the material properties such as bone mineralization and the quality of collagen, which are being influenced by bone turnover and accumulation of microdamage [63].

In diabetic patients, bone remodeling appears to be impaired as both markers of bone formation and markers of bone resorption are decreased when compared to healthy subjects [64-67]. The influence of glycemic control on bone turnover in T2DM patients is not clear, as the effect of glycemic control in different studies varies from a decrease to an increase in bone turnover markers [22,68-73].

For normal osteogenesis, the Wnt/ $\beta$-catenin pathyway is essential [74]. Serum sclerostin is an inhibitor of the Wnt/ $\beta$-catenin signaling pathway and is therefore an inhibitor of bone formation. Sclerostin was found to be significantly increased in T2DM patients when compared to people without T2DM $[66,67,75]$, and could thus be the cause of the decreased bone formation markers. Sclerostin is positively correlated with vertebral fractures in T2DM patients [66] and therapy with sclerostin-neutralizing monoclonal antibodies fully reverses the negative effect of T2DM on bone mass and strength in rats [76].

The quality of bone collagen can be impaired by accumulation of advanced glycation end products (AGEs). AGEs are a highly stable cross-linked product and are formed by a series of non-enzymatic reactions between glucose and proteins [77,78]. The level of AGE pentosidine was higher in T2DM patients [79], and it was positively correlated with incident clinical and prevalent vertebral fractures in T2DM patients, while no association between pentosidine and fracture risk could be found in nondiabetic subjects [78,79].

Elevated blood glucose levels lead to hypercalcuria [80], and could therefore influence bone mineralization. Despite the increased calcium loss due to renal leakage, serum levels of parathyroid hormone (PTH) seem to be lower in diabetic patients $[22,66]$. This state of functional hypoparathyroidism could play a role in the pathogenesis of the above described state of low bone turnover in diabetic subjects, as a negative correlation between sclerostin and PTH has been noticed in several studies [66,75,81]. The prevalence of hypovitaminosis $D$ in type 2 diabetic patients is high [82], but serum levels of vitamin D do not differ significantly between diabetic patients and healthy subjects [10,22].

Adiponectin is one the adipocytokines and is secreted from the adipose tissue [83]. Osteoblasts have been shown to have adiponectin receptors and the proliferation, differentiation and mineralization of osteoblastic cells are enhanced by adiponectin $[84,85]$. Adiponectin levels have been shown to be elevated during weight loss and decreased during weight gain [86]. Adiponectin levels in T2DM patients are inversely correlated with bone mass $[71,87]$ and positively associated with vertebral fractures in T2DM men [87]. The underlying mechanism has not been completely unraveled.

HR-pQCT can be used to take a close look at trabecular and cortical microarchitecture separately and to calculate bone strength indices. Up to date, only a few small studies have used HRpQCT to examine differences in bone microarchitecture between T2DM patients and nondiabetic subjects [49,50,72,88,89]. In most of these studies, there were no significant differences between HR-pQCT microarchitecture parameters between T2DM patients and healthy subjects $[72,88,89]$. Increased cortical porosity was found in T2DM patients with fragility fractures, when compared to diabetic patients without fragility fractures [88]. One study also showed greater cortical porosity between T2DM patients and control subjects, but after adjustment for fragility fractures, the difference disappeared $[49,88]$. No differences were found in bone strength between T2DM patients and healthy controls when using HR-pQCT parameters [49,88].

Changes in bone geometry can increase fracture risk due to a decreased bending strength of a specific bone and/or a decreased resistance to axial load [90]. Previous research showed that bone geometry adapts to changes in skeletal loading over time, whereby an increase in body weight was associated with an increase in section modulus (an index of bending and torsional strength) [91]. These changes in geometry are most probably due to differences in lean mass and muscle strength and thus a result of muscle loads on bone [91]. A recent study in obese women showed that a higher BMI was associated with lower indices of bone strength relative to load and that obesity, after adjustment for BMD, was associated with an increased fracture risk. This increased risk is probably due to larger fall impact forces on bone in these patients [92].

In diabetic patients, lean mass was able to predict hip strength [93]. As T2DM patients are known to have lower skeletal muscle strength and muscle quality [33], an unfavorable effect on bone geometry in T2DM patients would be expected. One study using peripheral quantitative computed tomography indeed showed that they had lower bone bending strength after adjustment for body weight, especially in the more cortical regions of the bone [50].

\subsubsection{The influence of antidiabetic drugs on bone fragility}

The use of thiazolidinediones (TZDs) has been associated with an increased fracture risk in both T2DM men and women when compared to non-diabetic patients and to diabetic patients using other blood glucose lowering drugs. As both rosiglitazone and pioglitazone show this increased risk, a class effect of TZDs is suggested [94-96]. TZDs could have a negative effect on bone quality, since they suppress the differentiation of mesenchymal stem cells into osteoblasts in favor of differentiation to adipocytes. In addition, TZD use is associated with a decrease in BMD at both the hip and spine, and after discontinuing the use of TZDs no further decline in BMD was found $[97,98]$.

Insulin stimulates bone formation [99], hence a direct negative effect of insulin on bone quality is not to be expected. Insulin use is associated with an increased fracture risk $[6,11,100]$. But this increased fracture risk was most probably due to an increased risk of falls because of hypoglycemic events and because insulin is often only used in patients with diabetes of longer duration and thus in patients who are likely to have long term negative hyperglycemic effects on bone quality [24,31,42].

Metformin is osteogenic in vitro [101] and a small gain in BMD at the femoral neck and lumbar spine in metformin users has been noted [97]. Most clinical studies found no positive or negative effect of metformin on fracture risk [102,103], although one study indeed showed a decreased risk for hip fractures in metformin users [104]. 
No difference in fracture risk could be found in patients using sulfonylureas, dipeptidyl peptidase-4 (DPP4) inhibitors, glucagonlike peptide 1 (GLP-1) agonists or sodium-glucose transport protein 2 (SGLT2) inhibitors [104-109] as compared to subjects without T2DM. In fact, DDP4 inhibitors and GLP-1 agonists possibly had a protective effect on bone due to the increase of circulating levels of GLP-1 and gastric intestinal polypeptide, which are both involved in the regulation of bone metabolism $[107,109,110]$.

\section{The usefulness of imaging modalities and fracture risk assessment tools}

\subsection{Imaging modalities}

DXA is the most commonly used technique for diagnosing osteoporosis and osteopenia. These diagnoses are defined as a $T$-score (a subjects aBMD compared to the mean BMD of a young adult reference population) of $\leq-2.5$ and between -1.0 and -2.5 respectively [111]. There is extensive literature available about DXA measurements in T2DM subjects, but less is known about the usefulness of the BMD measurements for the determination of fracture risk in this population. In three small studies, no association between BMD and the presence of prevalent vertebral fractures was found in T2DM patients $[20,112,113]$, but a large trial that used the prospective data from three observational studies found a negative association between femoral neck $T$-score and hip and nonspine fracture risk [114]. The ability to predict fracture risk based on $T$ score is the same in adults with and without T2DM [114]. However, fracture risk in T2DM patients for a given $T$-score is higher than fracture risk for the non-diabetic controls [114].

eBMD and calcaneal stiffness as measured with quantitative ultrasound are both significantly lower in type 2 diabetic patients with a prior fracture [28] and can therefore probably be used to determine fracture risk. One study however could not find a difference in speed of sound between type 2 diabetic patients with and without vertebral fractures [113].

Up to date, no studies have investigated the usefulness of HRpQCT in determining fracture risk.

\subsection{WHO fracture risk algorithm (FRAX $\left.X^{\circledR}\right)$}

The fracture risk assessment tool is developed by the World Health Organization in 2008 and can be used to predict the 10year risk of a major osteoporotic or hip fracture for a 40-90 year old subject. If available, BMD of the hip can also be entered into the FRAX $^{\circledR}$ algorithm [115].

The fracture risk of T2DM patients for both major osteoporotic and hip fractures seems comparable to the fracture risk for nondiabetic subjects according to the FRAX ${ }^{\circledR}$ algorithm, based on their clinical parameters and femoral neck BMD [116,117]. When only clinical parameters were used, fracture risk in diabetic subjects calculated with the FRAX ${ }^{\circledR}$ algorithm is lower than the fracture risk in a matched group of healthy controls [118].

Although FRAX ${ }^{\circledR}$ scores correlate with hip and nonspine fractures $[114,117,118], \mathrm{FRAX}^{\circledR}$ underestimates fracture risk in diabetic patients because observed fracture rates were higher than predicted when using the FRAX ${ }^{\circledR}$ algorithm [114,116-118]. One study showed that diabetes status is an independent predictor of hip and major osteoporotic fractures after adjustment for the clinical parameters as used in the FRAX ${ }^{\circledR}$ tool [117]. Another study showed that the association of major osteoporotic and hip fracture FRAX scores were higher when HbA1c and hypoglycemic events were added to the algorithm [118]. For hip fracture FRAX scores, the association also increases when macrovascular complications in men and neuropathy in women was added to the model [118].
Up to date, no studies have used other fracture risk assessment tools (such as the Garvan Fracture Risk Calculator) to determine fracture risk in T2DM patients.

\section{Conclusion}

In this overview we discussed the underlying mechanisms of the increased fracture risk in T2DM patients and of the usefulness of fracture risk assessment tools in predicting fracture risk in T2DM patients.

In T2DM patients, the increased fracture risk can be partly explained by an increased fall risk due to complications of the disease such as neuropathy and retinopathy. Although bone mass seems to be normal to elevated in T2DM patients, bone quality and thus bone strength is decreased due to changes in bone (micro)architecture and material properties such as bone mineralization and the quality of collagen when compared to nondiabetic patients. The use of antidiabetic drugs, especially TZD's, can also contribute to the increased fracture risk by decreasing both bone mass and quality.

DXA and FRAX ${ }^{\circledR}$ can be used to assess fracture risk in T2DM patients in clinical practice, but it is important to realize that they both underestimate the absolute fracture risk when compared to assessment in nondiabetic subjects. For a more accurate risk assessment, it could be useful to add T2DM as an extra risk factor to the FRAX $^{\circledR}$ tool. HR-pQCT is a promising new imaging modality because of its ability to get a virtual bone biopsy and to analyze bone strength in vivo. Therefore would it be interesting to determine its usefulness in the determination of fracture risk.

\section{Contributors}

E.A.C. de Waard, T.A.C.M. van Geel, H.H.C.M. Savelberg, A. Koster, P.P.M.M. Geusens and J.P.W. van den Bergh all participated in the planning, writing, correction and finalization of the article.

\section{Competing interest}

The authors declare no conflict of interest.

\section{Funding}

Research funding from "Stichting de Weijerhorst".

\section{Provenance and peer review}

Commissioned and externally peer reviewed.

\section{References}

[1] World Health Organization. Fact sheet ageing; 2012. Available from: http://www.who.int/ageing/about/facts/en/ [cited 27.02.14].

[2] World Health Organization. Fact sheet obesity; 2013. Available from: http://www.who.int/mediacentre/factsheets/fs311/en/ [cited 27.02.14].

[3] Danaei G, Finucane MM, Lu Y, et al. National, regional, and global trends in fasting plasma glucose and diabetes prevalence since 1980: systematic analysis of health examination surveys and epidemiological studies with 370 country-years and 2.7 million participants. Lancet 2011;378(9785):31-40, http://dx.doi.org/10.1016/s0140-6736(11)60679-x.

[4] Alberti KG, Zimmet PZ. Definition, diagnosis and classification of diabetes mellitus and its complications. Part 1: Diagnosis and classification of diabetes mellitus provisional report of a WHO consultation. Diabet Med 1998;15(7):539-53, http://dx.doi.org/

[5] Janghorbani M, Van Dam RM, Willett WC, Hu FB. Systematic review of type 1 and type 2 diabetes mellitus and risk of fracture. Am J Epidemiol 2007;166(5):495-505, http://dx.doi.org/10.1093/aje/kwm106. 
[6] Ahmed LA, Joakimsen RM, Berntsen GK, Fonnebo V, Schirmer H. Diabetes mellitus and the risk of non-vertebral fractures: the Tromso study. Osteoporos Int 2006;17(4):495-500, http://dx.doi.org/10.1007/s00198-005-0013-x.

[7] Bonds DE, Larson JC, Schwartz AV, et al. Risk of fracture in women with type 2 diabetes: the Women's Health Initiative Observational Study. J Clin Endocrinol Metab 2006;91(9):3404-10, http://dx.doi.org/10.1210/jc.2006-0614.

[8] Chen HF, Ho CA, Li CY. Increased risks of hip fracture in diabetic patients of Taiwan: a population-based study. Diabetes Care 2008;31(1):75-80, http://dx.doi.org/10.2337/dc07-1072.

[9] de Liefde II, van der Klift M, de Laet CE, van Daele PL, Hofman A, Pols HA. Bone mineral density and fracture risk in type-2 diabetes mellitus: the Rotterdam Study. Osteoporos Int 2005;16(12):1713-20, http://dx.doi.org/10.1007/s00198-005-1909-1.

[10] Gerdhem P, Isaksson A, Akesson K, Obrant KJ. Increased bone density and decreased bone turnover, but no evident alteration of fracture susceptibility in elderly women with diabetes mellitus. Osteoporos Int 2005;16(12):1506-12, http://dx.doi.org/10.1007/s00198-005-1877-5.

[11] Janghorbani M, Feskanich D, Willett WC, Hu F. Prospective study of diabetes and risk of hip fracture: the Nurses' Health Study. Diabetes Care 2006;29(7):1573-8, http://dx.doi.org/10.2337/dc06-0440.

[12] Khalil N, Sutton-Tyrrell K, Strotmeyer ES, et al. Menopausal bone changes and incident fractures in diabetic women: a cohort study. Osteoporos Int 2011;22(5):1367-76, http://dx.doi.org/10.1007/s00198-010-1357-4.

[13] Leslie WD, Lix LM, Prior HJ, Derksen S, Metge C, O’Neil J. Biphasic fracture risk in diabetes: a population-based study. Bone 2007;40(6):1595-601, http://dx.doi.org/10.1016/j.bone.2007.02.021.

[14] Lipscombe LL, Jamal SA, Booth GL, Hawker GA. The risk of hip fractures in older individuals with diabetes: a population-based study. Diabetes Care 2007;30(4):835-41, http://dx.doi.org/10.2337/dc06-1851.

[15] Melton LJ, 3rd, Leibson CL, Achenbach SJ, Therneau TM, Khosla S. Fracture risk in type 2 diabetes: update of a population-based study. J Bone Miner Res 2008;23(8):1334-42, http://dx.doi.org/10.1359/jbmr.080323.

[16] Strotmeyer ES, Cauley JA, Schwartz AV, et al. Nontraumatic fracture risk with diabetes mellitus and impaired fasting glucose in older white and black adults: the health, aging, and body composition study. Arch Intern Med 2005;165(14):1612-7, http://dx.doi.org/10.1001/archinte.165.14.1612.

[17] Vestergaard P. Discrepancies in bone mineral density and fracture risk in patients with type 1 and type 2 diabetes - a meta-analysis. Osteoporos Int 2007;18(4):427-44, http://dx.doi.org/10.1007/s00198-006-0253-4.

[18] Vestergaard P, Rejnmark L, Mosekilde L. Relative fracture risk in patients with diabetes mellitus, and the impact of insulin and oral antidiabetic medication on relative fracture risk. Diabetologia 2005;48(7):1292-9, http://dx.doi.org/10.1007/s00125-005-1786-3.

[19] Viegas M, Costa C, Lopes A, Griz L, Medeiro MA, Bandeira F. Prevalence of osteoporosis and vertebral fractures in postmenopausal women with type 2 diabetes mellitus and their relationship with duration of the disease and chronic complications. J Diabetes Complic 2011;25(4):216-21, http://dx.doi.org/10.1016/j.jdiacomp.2011.02.004.

[20] Yamamoto M, Yamaguchi T, Yamauchi M, Kaji H, Sugimoto T. Diabetic patients have an increased risk of vertebral fractures independent of BMD or diabetic complications. J Bone Miner Res 2009;24(4):702-9, http://dx.doi.org/10.1359/jbmr.081207.

[21] Chung DJ, Choi HJ, Chung YS, Lim SK, Yang SO, Shin CS. The prevalence and risk factors of vertebral fractures in Korean patients with type 2 diabetes. J Bone Miner Metab 2013;31(2):161-8, http://dx.doi.org/10.1007/s00774-012-0398-5.

[22] Dobnig H, Piswanger-Solkner JC, Roth $\mathrm{M}$, et al. Type 2 diabetes mellitus in nursing home patients: effects on bone turnover, bone mass, and fracture risk. J Clin Endocrinol Metab 2006;91(9):3355-63, http://dx.doi.org/10.1210/jc.2006-0460.

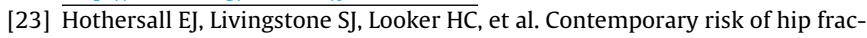
ture in type 1 and type 2 diabetes: a national registry study from Scotland. J Bone Miner Res 2014;29(5):1054-60, http://dx.doi.org/10.1002/jbmr.2118.

[24] Roman de Mettelinge T, Cambier D, Calders P, Van Den Noortgate N, Delbaere K. Understanding the relationship between type 2 diabetes mellitus and falls in older adults: a prospective cohort study. PLOS ONE 2013;8(6):e67055, http://dx.doi.org/10.1371/journal.pone.0067055.

[25] Tilling LM, Darawil K, Britton M. Falls as a complication of diabetes mellitus in older people. J Diabetes Complic 2006;20(3):158-62, http://dx.doi.org/10.1016/j.jdiacomp.2005.06.004.

[26] Maurer MS, Burcham J, Cheng H. Diabetes mellitus is associated with an increased risk of falls in elderly residents of a longterm care facility. J Gerontol Ser A Biol Sci Med Sci 2005;60(9): 1157-62.

[27] Oliveira PP, Fachin SM, Tozatti J, Ferreira MC, Marinheiro LP. Comparative analysis of risk for falls in patients with and without type 2 diabetes mellitus. Rev Assoc Med Bras 2012;58(2):234-9.

[28] Patel S, Hyer S, Tweed K, et al. Risk factors for fractures and falls in older women with type 2 diabetes mellitus. Calcif Tissue Int 2008;82(2):87-91, http://dx.doi.org/10.1007/s00223-007-9082-5.
[29] Macgilchrist C, Paul L, Ellis BM, Howe TE, Kennon B, Godwin J. Lowerlimb risk factors for falls in people with diabetes mellitus. Diabet Med 2010;27(2):162-8, http://dx.doi.org/10.1111/j.1464-5491.2009.02914.x.

[30] Agrawal Y, Carey JP, Della Santina CC, Schubert MC, Minor LB. Diabetes, vestibular dysfunction, and falls: analyses from the National Health and Nutrition Examination Survey. Otol Neurotol 2010;31(9):1445-50, http://dx.doi.org/10.1097/MA0.0b013e3181f2f035.

[31] Pijpers E, Ferreira I, de Jongh RT, et al. Older individuals with diabetes have an increased risk of recurrent falls: analysis of potential mediating factors: the Longitudinal Ageing Study Amsterdam. Age Ageing 2012;41(3):358-65, http://dx.doi.org/10.1093/ageing/afr145.

[32] IJzerman TH, Schaper NC, Melai T, Meijer K, Willems PJ, Savelberg HH Lower extremity muscle strength is reduced in people with type 2 diabetes, with and without polyneuropathy, and is associated with impaired mobility and reduced quality of life. Diabetes Res Clin Pract 2012;95(3):345-51, http://dx.doi.org/10.1016/j.diabres.2011.10.026.

[33] Park SW, Goodpaster BH, Strotmeyer ES, et al. Decreased muscle strength and quality in older adults with type 2 diabetes: the health, aging, and body composition study. Diabetes 2006;55(6):1813-8, http://dx.doi.org/10.2337/db05-1183.

[34] Lalli P, Chan A, Garven A, et al. Increased gait variability in diabetes mellitus patients with neuropathic pain. J Diabetes Complic 2013;27(3):248-54, http://dx.doi.org/10.1016/j.jdiacomp.2012.10.013.

[35] Zochodne DW. Diabetic polyneuropathy: an update. Curr Opin Neuro 2008;21(5):527-33, http://dx.doi.org/10.1097/WCO.0b013e32830b84cb.

[36] van Hateren KJ, Kleefstra N, Blanker MH, et al. Orthostatic hypotension, diabetes, and falling in older patients: a cross-sectional study. Brit J Gen Pract 2012;62(603):e696-702, http://dx.doi.org/10.3399/bjgp12X656838.

[37] Greenspan SL, Myers ER, Kiel DP, Parker RA, Hayes WC, Resnick NM. Fall direction, bone mineral density, and function: risk factors for hip fracture in frail nursing home elderly. Am J Med 1998;104(6):539-45.

[38] Greenspan SL, Myers ER, Maitland LA, Resnick NM, Hayes WC. Fall severity and bone mineral density as risk factors for hip fracture in ambulatory elderly. JAMA 1994;271(2):128-33.

[39] Lee CG, Schwartz AV, Yaffe K, Hillier TA, LeBlanc ES, Cawthon PM. Changes in physical performance in older women according to presence and treatment of diabetes mellitus. J Am Geriatr Soc 2013;61(11):1872-8, http://dx.doi.org/10.1111/jgs.12502.

[40] Wu JS, Yang YC, Lu FH, Wu CH, Wang RH, Chang CJ. Population-based study on the prevalence and risk factors of orthostatic hypotension in subjects with pre-diabetes and diabetes. Diabetes Care 2009;32(1):69-74, http://dx.doi.org/10.2337/dc08-1389.

[41] Romero-Ortuno R, Cogan L, Foran T, Kenny RA, Fan CW. Continuous noninvasive orthostatic blood pressure measurements and their relationship with orthostatic intolerance, falls, and frailty in older people. J Am Geriatr Soc 2011;59(4):655-65, http://dx.doi.org/10.1111/j.1532-5415.2011.03352.x.

[42] Huang ES, Karter AJ, Danielson KK, Warton EM, Ahmed AT. The association between the number of prescription medications and incident falls in a multi-ethnic population of adult type- 2 diabetes patients: the diabetes and aging study. J Gen Intern Med 2010;25(2):141-6, http://dx.doi.org/10.1007/s11606-009-1179-2.

[43] Tranquilli Leali P, Doria C, Zachos A, Ruggiu A, Milia F, Barca F. Bone fragility: current reviews and clinical features. Clin Cases Miner Bone Metab 2009;6(2):109-13.

[44] Ma L, Oei L, Jiang L, et al. Association between bone mineral density and type 2 diabetes mellitus: a meta-analysis of observational studies. Eur J Epidemio 2012;27(5):319-32, http://dx.doi.org/10.1007/s10654-012-9674-x.

[45] Abdulameer SA, Sulaiman SA, Hassali MA, Subramaniam K, Sahib MN. Osteoporosis and type 2 diabetes mellitus: what do we know and what we can do? Patient Prefer Adherence 2012;6:435-48, http://dx.doi.org/10.2147/PPA.S32745.

[46] Gorman E, Chudyk AM, Madden KM, Ashe MC. Bone health and type 2 diabetes mellitus: a systematic review. Physiother Can 2011;63(1):8-20, http://dx.doi.org/10.3138/ptc.2010-23bh.

[47] Chin KY, Ima-Nirwana S. Calcaneal quantitative ultrasound as a determinant of bone health status: what properties of bone does it reflect? Int J Med Sci 2013;10(12):1778-83, http://dx.doi.org/10.7150/ijms.6765.

[48] MacNeil JA, Boyd SK. Accuracy of high-resolution peripheral quantitative computed tomography for measurement of bone quality. Med Eng Phys 2007;29(10):1096-105, http://dx.doi.org/10.1016/j.medengphy.2006.11.002.

[49] Burghardt AJ, Issever AS, Schwartz AV, et al. High-resolution periphera quantitative computed tomographic imaging of cortical and trabecular bone microarchitecture in patients with type 2 diabetes mellitus. J Clin Endocrinol Metab 2010;95(11):5045-55, http://dx.doi.org/10.1210/jc.2010-0226.

[50] Petit MA, Paudel ML, Taylor BC, et al. Bone mass and strength in older men with type 2 diabetes: the Osteoporotic Fractures in Men Study. J Bone Miner Res 2010;25(2):285-91, http://dx.doi.org/10.1359/jbmr.090725.

[51] Schwartz AV, Ewing SK, Porzig AM, et al. Diabetes and change in bone mineral density at the hip, calcaneus, spine, and radius in older women. Front Endocrinol 2013;4:62, http://dx.doi.org/10.3389/fendo.2013.00062. 
[52] Hamilton EJ, Rakic V, Davis WA, et al. A five-year prospective study of bone mineral density in men and women with diabetes: the Fremantle Diabetes Study. Acta Diabetol 2012;49(2):153-8, http://dx.doi.org/10.1007/s00592-011-0324-7.

[53] Bridges MJ, Moochhala SH, Barbour J, Kelly CA. Influence of diabetes on peripheral bone mineral density in men: a controlled study. Acta Diabetol 2005:42(2):82-6, http://dx.doi.org/10.1007/s00592-005-0183-1.

[54] Tao B, Liu JM, Zhao HY, et al. Differences between measurements of bone mineral densities by quantitative ultrasound and dual-energy X-ray absorptiometry in type 2 diabetic postmenopausal women. J Clin Endocrinol Metab 2008;93(5):1670-5, http://dx.doi.org/10.1210/jc.2007-1760.

[55] Vasilkova O, Mokhort T, Sanec I, Sharshakova T, Hayashida N, Takamura $\mathrm{N}$. Testosterone is an independent determinant of bone mineral density in men with type 2 diabetes mellitus. Clin Chem Lab Med 2011;49(1):99-103, http://dx.doi.org/10.1515/cclm.2011.016.

[56] Hadjidakis DI, Androulakis II, Mylonakis AM, et al. Diabetes in postmenopause: different influence on bone mass according to age and disease duration. Exp Clin Endocrinol Diabetes 2009;117(5):199-204, http://dx.doi.org/10.1055/s-2008-1080921.

[57] Di Somma C, Rubino M, Faggiano A, et al. Spinal deformity index in patients with type 2 diabetes. Endocrine 2013;43(3):651-8, http://dx.doi.org/10.1007/s12020-012-9848-z.

[58] Anaforoglu I, Nar-Demirer A, Bascil-Tutuncu N, Ertorer ME. Prevalence of osteoporosis and factors affecting bone mineral density among postmenopausal Turkish women with type 2 diabetes. J Diabetes Complic 2009;23(1):12-7, http://dx.doi.org/10.1016/j.jdiacomp.2007.06.004.

[59] Strotmeyer ES, Cauley JA, Schwartz AV, et al. Diabetes is associated independently of body composition with BMD and bone volume in older white and black men and women: the Health, Aging, and Body Composition Study.J Bone Miner Res 2004;19(7):1084-91, http://dx.doi.org/10.1359/jbmr.040311.

[60] Majima T, Komatsu Y, Yamada T, et al. Decreased bone mineral density at the distal radius, but not at the lumbar spine or the femoral neck, in Japanese type 2 diabetic patients. Osteoporos Int 2005:16(8):907-13, http://dx.doi.org/10.1007/s00198-004-1786-z.

[61] Zhou Y, Li Y, Zhang D, Wang J, Yang H. Prevalence and predictors of osteopenia and osteoporosis in postmenopausal Chinese women with type 2 diabetes. Diabetes Res Clin Pract 2010;90(3):261-9, http://dx.doi.org/10.1016/j.diabres.2010.09.013.

[62] Bouxsein ML. Mechanisms of osteoporosis therapy: a bone strength perspective. Clin Cornerstone 2003;(Suppl. 2):S13-21.

[63] Donnelly E. Methods for assessing bone quality: a review. Clin Orthop 2011:469(8):2128-38, http://dx.doi.org/10.1007/s11999-010-1702-0.

[64] Oz SG, Guven GS, Kilicarslan A, Calik N, Beyazit Y, Sozen T. Evaluation of bone metabolism and bone mass in patients with type-2 diabetes mellitus. J Natl Med Assoc 2006;98(10):1598-604.

[65] Gaudio A, Privitera F, Battaglia K, et al. Sclerostin levels associated with inhibition of the Wnt/beta-catenin signaling and reduced bone turnover in type 2 diabetes mellitus. J Clin Endocrinol Metab 2012;97(10):3744-50, http://dx.doi.org/10.1210/jc.2012-1901.

[66] Ardawi MS, Akhbar DH, Alshaikh A, et al. Increased serum sclerostin and decreased serum IGF-1 are associated with vertebral fractures among postmenopausal women with type-2 diabetes. Bone 2013;56(2):355-62, http://dx.doi.org/10.1016/j.bone.2013.06.029.

[67] Gennari L, Merlotti D, Valenti R, et al. Circulating sclerostin levels and bone turnover in type 1 and type 2 diabetes. J Clin Endocrinol Metab 2012;97(5):1737-44, http://dx.doi.org/10.1210/jc.2011-2958.

[68] Capoglu I, Ozkan A, Ozkan B, Umudum Z. Bone turnover markers in patients with type 2 diabetes and their correlation with glycosylated haemoglobin levels. J Int Med Res 2008;36(6): $1392-8$

[69] Kanazawa I, Yamaguchi T, Yamauchi M, et al. Adiponectin is associated with changes in bone markers during glycemic control in type 2 diabetes mellitus. J Clin Endocrinol Metab 2009;94(8):3031-7, http://dx.doi.org/10.1210/jc.2008-2187.

[70] Kanazawa I, Yamaguchi T, Yamamoto M, Yamauchi M, Yano S, Sugimoto T. Serum osteocalcin/bone-specific alkaline phosphatase ratio is a predictor for the presence of vertebral fractures in men with type 2 diabetes. Calcif Tissue Int 2009;85(3):228-34, http://dx.doi.org/10.1007/s00223-009-9272-4.

[71] Miazgowski T, Noworyta-Zietara M, Safranow K, Ziemak J, Widecka $\mathrm{K}$. Serum adiponectin, bone mineral density and bone turnover markers in post-menopausal women with newly diagnosed Type 2 diabetes: a 12-month follow-up. Diabet Med 2012;29(1):62-9, http://dx.doi.org/10.1111/j.1464-5491.2011.03381.x.

[72] Shu A, Yin MT, Stein E, et al. Bone structure and turnover in type 2 diabetes mellitus. Osteoporos Int 2012;23(2):635-41, http://dx.doi.org/10.1007/s00198-011-1595-0.

[73] Rasul S, Ilhan A, Wagner L, Luger A, Kautzky-Willer A. Diabetic polyneuropathy relates to bone metabolism and markers of bone turnover in elderly patients with type 2 diabetes: greater effects in male patients. Gend Med 2012;9(3):187-96, http://dx.doi.org/10.1016/j.genm.2012.03.004

[74] Day TF, Guo X, Garrett-Beal L, Yang Y. Wnt/beta-catenin signaling in mesenchymal progenitors controls osteoblast and chondrocyte differentiation during vertebrate skeletogenesis. Dev Cell 2005;8(5):739-50, http://dx.doi.org/10.1016/j.devcel.2005.03.016.

[75] Garcia-Martin A, Rozas-Moreno P, Reyes-Garcia R, et al. Circulating levels of sclerostin are increased in patients with type 2 diabetes mellitus. J Clin Endocrinol Metab 2012;97(1):234-41, http://dx.doi.org/10.1210/jc.2011-2186.

[76] Hamann C, Rauner M, Hohna Y, et al. Sclerostin antibody treatment improves bone mass, bone strength, and bone defect regeneration in rats with type 2 diabetes mellitus. J Bone Miner Res 2013;28(3):627-38, http://dx.doi.org/10.1002/jbmr.1803.

[77] Goh SY, Cooper ME. Clinical review: the role of advanced glycation end products in progression and complications of diabetes. J Clin Endocrinol Metab 2008;93(4):1143-52, http://dx.doi.org/10.1210/jc.2007-1817.

[78] Schwartz AV, Garnero P, Hillier TA, et al. Pentosidine and increased fracture risk in older adults with type 2 diabetes. J Clin Endocrinol Metab 2009;94(7):2380-6, http://dx.doi.org/10.1210/jc.2008-2498.

[79] Yamamoto M, Yamaguchi T, Yamauchi M, Yano S, Sugimoto T. Serum pentosidine levels are positively associated with the presence of vertebral fractures in postmenopausal women with type 2 diabetes. J Clin Endocrinol Metab 2008;93(3):1013-9, http://dx.doi.org/10.1210/jc.2007-1270.

[80] Gregorio F, Cristallini S, Santeusanio F, Filipponi P, Fumelli P. Osteopenia associated with non-insulin-dependent diabetes mellitus: what are the causes? Diabetes Res Clin Pract 1994;23(1):43-54.

[81] Zhou YJ, Li A, Song YL, Zhou H, Li Y, Tang YS. Role of sclerostin in the bone loss of postmenopausal chinese women with type 2 diabetes. Chin Med Sci J 2013;28(3):135-9.

[82] Filippella MG, Faggiano A, Falchetti A, et al. Risk of fractures and bone abnormalities in postmenopausal women with type 2 diabetes mellitus. Clin Cases Miner Bone Metab 2010;7(2):126-9.

[83] Maeda K, Okubo K, Shimomura I, Mizuno K, Matsuzawa Y, Matsubara K. Analysis of an expression profile of genes in the human adipose tissue. Gene 1997;190(2):227-35

[84] Kanazawa I, Yamaguchi T, Yano S, Yamauchi M, Yamamoto M, Sugimoto T Adiponectin and AMP kinase activator stimulate proliferation, differentiation, and mineralization of osteoblastic MC3T3-E1 cells. BMC Cell Biol 2007;8(51.), http://dx.doi.org/10.1186/1471-2121-8-51.

[85] Berner HS, Lyngstadaas SP, Spahr A, et al. Adiponectin and its receptors are expressed in bone-forming cells. Bone 2004;35(4):842-9, http://dx.doi.org/10.1016/j.bone.2004.06.008.

[86] Arita Y, Kihara S, Ouchi N, et al. Paradoxical decrease of an adiposespecific protein, adiponectin, in obesity. Biochem Biophys Res Commun 1999;257(1):79-83.

[87] Kanazawa I, Yamaguchi T, Yamamoto M, Yamauchi M, Yano S, Sugimoto T. Relationships between serum adiponectin levels versus bone mineral density, bone metabolic markers, and vertebral fractures in type 2 diabetes mellitus. Eur J Endocrinol 2009;160(2):265-73, http://dx.doi.org/10.1530/eje-08-0642.

[88] Patsch JM, Burghardt AJ, Yap SP, et al. Increased cortical porosity in type 2 diabetic postmenopausal women with fragility fractures. J Bone Miner Res 2013;28(2):313-24, http://dx.doi.org/10.1002/jbmr.1763.

[89] Farr JN, Drake MT, Amin S, Melton 3rd LJ, McCready LK, Khosla S. In vivo assessment of bone quality in postmenopausal women with type 2 diabetes. J Bone Miner Res 2014;29(4):787-95, http://dx.doi.org/10.1002/jbmr.2106.

[90] Garg R, Chen Z, Beck T, et al. Hip geometry in diabetic women: implications for fracture risk. Metabolism 2012;61(12):1756-62, http://dx.doi.org/10.1016/j.metabol.2012.05.010.

[91] Beck TJ, Oreskovic TL, Stone KL, et al. Structural adaptation to changing skeletal load in the progression toward hip fragility: the study of osteoporotic fractures. J Bone Miner Res 2001;16(6):1108-19, http://dx.doi.org/10.1359/jbmr.2001.16.6.1108.

[92] Ishii S, Cauley JA, Greendale GA, et al. Pleiotropic effects of obesity on fracture risk: the study of women's health across the nation. J Bone Miner Res 2014, http://dx.doi.org/10.1002/jbmr.2303.

[93] Moseley KF, Dobrosielski DA, Stewart KJ, Sellmeyer DE, Jan De Beur SM. Lean mass predicts hip geometry in men and women with non-insulinrequiring type 2 diabetes mellitus. J Clin Densitom 2011;14(3):332-9, http://dx.doi.org/10.1016/j.jocd.2011.04.007.

[94] Bennett WL, Maruthur NM, Singh S, et al. Comparative effectiveness and safety of medications for type 2 diabetes: an update including new drugs and 2-drug combinations. Ann Intern Med 2011;154(9):602-13, http://dx.doi.org/10.7326/0003-4819-154-9-201105030-00336.

[95] Bazelier MT, Gallagher AM, van Staa TP, et al. Use of thiazolidinediones and risk of osteoporotic fracture: disease or drugs? Pharmacoepidemiol Drug Saf 2012;21(5):507-14, http://dx.doi.org/10.1002/pds.3234.

[96] Colhoun HM, Livingstone SJ, Looker HC, et al. Hospitalised hip fracture risk with rosiglitazone and pioglitazone use compared with other glucose-lowering drugs. Diabetologia 2012;55(11):2929-37, http://dx.doi.org/10.1007/s00125-012-2668-0.

[97] Bilezikian JP, Josse RG, Eastell R, et al. Rosiglitazone decreases bone mineral density and increases bone turnover in postmenopausal women with type 2 diabetes mellitus. J Clin Endocrinol Metab 2013;98(4):1519-28, http://dx.doi.org/10.1210/jc.2012-4018. 
[98] Yaturu S, Bryant B, Jain SK. Thiazolidinedione treatment decreases bone mineral density in type 2 diabetic men. Diabetes Care 2007;30(6):1574-6, http://dx.doi.org/10.2337/dc06-2606.

[99] Thrailkill KM, Lumpkin Jr CK, Bunn RC, Kemp SF, Fowlkes JL. Is insulin an anabolic agent in bone? Dissecting the diabetic bone for clues. Am J Phys Endocrinol Metab 2005;289(5):E735-45, http://dx.doi.org/10.1152/ajpendo.00159.2005.

[100] Kim JH, Jung MH, Lee JM, Son HS, Cha BY, Chang SA. Diabetic peripheral neuropathy is highly associated with nontraumatic fractures in Korean patients with type 2 diabetes mellitus. Clin Endocrinol (Oxf) 2012;77(1):51-5, http://dx.doi.org/10.1111/j.1365-2265.2011.04222.x.

[101] Cortizo AM, Sedlinsky C, McCarthy AD, Blanco A, Schurman L. Osteogenic actions of the anti-diabetic drug metformin on osteoblasts in culture. Eur J Pharmacol 2006;536(1-2):38-46, http://dx.doi.org/10.1016/j.ejphar.2006.02.030.

[102] Jeyabalan J, Viollet B, Smitham P, et al. The anti-diabetic drug metformin does not affect bone mass in vivo or fracture healing. Osteoporos Int 2013;24(10):2659-70, http://dx.doi.org/10.1007/s00198-013-2371-0.

[103] Monami M, Cresci B, Colombini A, et al. Bone fractures and hypoglycemic treatment in type 2 diabetic patients: a case-control study. Diabetes Care 2008;31(2):199-203, http://dx.doi.org/10.2337/dc07-1736.

[104] Puar TH, Khoo JJ, Cho LW, et al. Association between glycemic control and hip fracture. J Am Geriatr Soc 2012;60(8):1493-7, http://dx.doi.org/10.1111/j.1532-5415.2012.04052.x.

[105] Ljunggren $\mathrm{O}$, Bolinder J, Johansson L, et al. Dapagliflozin has no effect on markers of bone formation and resorption or bone mineral density in patients with inadequately controlled type 2 diabetes mellitus on metformin. Diabetes Obes Metab 2012;14(11):990-9, http://dx.doi.org/10.1111/j.1463-1326.2012.01630.x.

[106] Mabilleau G, Mieczkowska A, Chappard D. Use of glucagon-like peptide-1 receptor agonists and bone fractures: a meta-analysis of randomized clinical trials. J Diabetes 2013, http://dx.doi.org/ 10.1111/1753-0407.12102.

[107] Monami M, Dicembrini I, Antenore A, Mannucci E. Dipeptidyl peptidase4 inhibitors and bone fractures: a meta-analysis of randomized clinical trials. Diabetes Care 2011;34(11):2474-6, http://dx.doi.org/ 10.2337/dc11-1099.
[108] Lapane KL, Yang S, Brown MJ, Jawahar R, Pagliasotti C, Rajpathak S. Sulfonylureas and risk of falls and fractures: a systematic review. Drugs Aging 2013;30(7):527-47, http://dx.doi.org/10.1007/s40266-013-0081-0.

[109] Hegazy SK. Evaluation of the anti-osteoporotic effects of metformin and sitagliptin in postmenopausal diabetic women. J Bone Miner Metab 2014 http://dx.doi.org/10.1007/s00774-014-0581-y.

[110] Nuche-Berenguer B, Moreno P, Esbrit P, et al. Effect of GLP1 treatment on bone turnover in normal, type 2 diabetic, and insulin-resistant states. Calcif Tissue Int 2009;84(6):453-61, http://dx.doi.org/10.1007/s00223-009-9220-3.

[111] Kanis JA, Melton 3rd LJ, Christiansen C, Johnston CC, Khaltaev N. The diagnosis of osteoporosis. J Bone Miner Res 1994;9(8):1137-41, http://dx.doi.org/10.1002/jbmr.5650090802.

[112] Yamamoto M, Yamaguchi T, Yamauchi M, Kaji H, Sugimoto T. Bone mineral density is not sensitive enough to assess the risk of vertebral fractures in type 2 diabetic women. Calcif Tissue Int 2007;80(6):353-8, http://dx.doi.org/10.1007/s00223-007-9003-7.

[113] Yamaguchi T, Yamamoto M, Kanazawa I, et al. Quantitative ultrasound and vertebral fractures in patients with type 2 diabetes. J Bone Miner Metab 2011;29(5):626-32, http://dx.doi.org/10.1007/s00774-011-0265-9.

[114] Schwartz AV, Vittinghoff E, Bauer DC, et al. Association of BMD and FRAX score with risk of fracture in older adults with type 2 diabetes. JAMA 2011;305(21):2184-92, http://dx.doi.org/10.1001/jama.2011.715.

[115] WHO Collaborating Centre for Metabolic Bone Diseases. Available from: http://www.shef.ac.uk/FRAX/tool.aspx? country=30 [Cited 01.07.14].

[116] Bhattoa HP, Onyeka U, Kalina E, et al. Bone metabolism and the 10-year probability of hip fracture and a major osteoporotic fracture using the country-specific FRAX algorithm in men over 50 years of age with type 2 diabetes mellitus: a case-control study. Clin Rheumatol 2013;32(8):1161-7, http://dx.doi.org/10.1007/s10067-013-2254-y.

[117] Giangregorio LM, Leslie WD, Lix LM, et al. FRAX underestimates frac ture risk in patients with diabetes. J Bone Miner Res 2012;27(2):301-8 http://dx.doi.org/10.1002/jbmr.556.

[118] Carnevale V, Morano S, Fontana A, et al. Assessment of fracture risk by the FRAX algorithm in men and women with and without type 2 diabetes mellitus: a cross-sectional study. Diabetes Metab Res Rev 2014;30(4):313-22. http://dx.doi.org/10.1002/dmrr.2497. 